\title{
Pre-sowing treatment effects on gutgutiya (protium serratum)- a threatened tree species of Bangladesh
}

\begin{abstract}
Gutgutiya (Protium serratum) is a native threatened multipurpose tree species of hill forests of Bangladesh. Fruits of this species are edible and contain high medicinal value. This species is naturally propagated by seeds. Natural germination percentage and final survivability in natural condition of this species is low. Pre-sowing treatment effects on seeds of P. serratum was studied to find out the best pre-sowing method for this hard coated seeds for restoration of degraded and deforested land. Randomized completely block design was applied and randomly selected seeds were treated with nine different pre-sowing treatments. Seeds were sown in normal polybags with 3:1 soil and cowdung media, and propagator house with Sylhet sand media. Highest germination percentage $(30 \%)$, plant percent $(30 \%)$ and germination value $(0.4)$ found in seeds sowing without any pre-sowing treatment followed by $10 \% \mathrm{H}_{2} \mathrm{SO}_{4}$ treatment for 3 minutes and $10 \% \mathrm{HCl}$ treatment for 3 minutes. Germination energy was highest $(6.7 \%)$ in boiled water but other germination performances and seedling growth performances were lowest. No germination observed in propagator house. Shoot height $(28.8 \mathrm{~cm})$, leaf number $(16)$, leaf size $(12.7 \mathrm{~cm} \times 4.7 \mathrm{~cm})$ and collar diameter $(12 \mathrm{~mm})$ were maximum in seedlings germinated by $10 \% \mathrm{HCl}$ treatment for 3 minutes followed by $10 \% \mathrm{H}_{2} \mathrm{SO}_{4}$ treatment for 3 minutes and $10 \% \mathrm{H}_{2} \mathrm{SO}_{4}$ treatment for 1 minute. The result of the study revealed that with increasing of immersion time in acid increases germination and seedling growth performances. The findings of this paper recommend $10 \% \mathrm{HCl}$ for 3 minutes and $10 \% \mathrm{H}_{2} \mathrm{SO}_{4}$ for 3 minutes for better performances in germination and seedling growth. This paper also recommend here for further researches on different concentration of $\mathrm{HCl}$ and $\mathrm{H}_{2} \mathrm{SO}_{4}$ for different time period on this valuable species.
\end{abstract}

Keywords: Protium serratum, native tree species, pre-sowing method, germination, seedling growth
Volume 2 Issue 6 - 2018

\author{
GN Tanjina Hasnat,' Mohammed Kamal \\ Hossain ${ }^{2}$ \\ 'Department of Land Administration, Patuakhali Science and \\ Technology University, Bangladesh \\ Institute of Forestry and Environmental Sciences, University of \\ Chittagong, Bangladesh
}

Correspondence: Tanjina Hasnat, Department of Land Administration, Patuakhali Science and Technology University, Dumki, Patuakhali-8602, Bangladesh, Tel +880I 783-736689, Email gnthesnat@gmail.com

Received:September II, 2018 | Published: November 30

2018

\section{Introduction}

Land is the most essential part of the world but is degrading day by day due to rapid deforestation and use of forest land into other land uses. Restoration of these degraded lands with ecologically and economically potential and naturally threatened tree species could save both the species and the land. Gutgutiya (Protium serratum Wall. ex Colebr.) belongs to the family Burseraceae ${ }^{1,2}$ is an evergreen perennial tree with a large, spreading crown. ${ }^{3}$ It is a native rare tree species in Bangladesh and found in deciduous and semi-evergreen forests of the hill tracts in Bangladesh. ${ }^{4,5}$ The plant also distributed throughout India, Laos, Thailand, Vietnam, Andaman Island, Myanmar, Pakistan, China, and Cambodia. ${ }^{6}$ The synonym of the tree is Bursera serrata and in Bengali it is known as Gutgutiya. It is a medium to large sized tree can grow up to $30 \mathrm{~m} \mathrm{tall}^{3}$ and diameter from 100 to $250 \mathrm{~cm}$. This tree usually grows along the stream side. ${ }^{7}$ Bole is short ${ }^{3}$ and mostly clear for 9 to $15 \mathrm{~m}$. Leaves are compound and leaf blade shape varies from oblong, oblong-lanceolate to acuminate. Flowers borne in densely velvety panicles in leaf axils. Flowers are bisexual, light green in color and carried on $2 \mathrm{~mm}$ long stalks. Fruit drupe type and nearly ovoid to round shaped. Fruits are yellowish green in young and bright pink when mature. ${ }^{5}$ Each fruit contains $1-3$ seeds. ${ }^{3} P$. serratum is a multipurpose tree species and different parts of the tree is widely used throughout the world as food, medicine and wood. This plant and plant parts is important for its potentiality of curing different diseases and allelopathic activity ${ }^{8}$ Mature fruit flesh is juicy, edible and sometimes used in manufacturing incense and perfumes.
The fruits are used in the treatment of mouth ulcers. ${ }^{3}$ The fruits also possess good antioxidant and extracts of fruits may effectively prevent DNA nicking. ${ }^{9}$ Oral ingestion of leaf extract of $P$. serratum is a highly effective treatment against gastrointestinal disease and stomach ulcer. ${ }^{10}$ Leaf extract of the tree is also a good antibacterial agent in food packaging and preservation. ${ }^{11}$ The extract from leaves have remarkable anti-arthritic and thrombolytic effect too. ${ }^{12}$

Paste of barks is applied as folk medicine on boils and scabies. ${ }^{13}$ Like other members of Burseraceae P. serratum produce aromatic resins or gums. ${ }^{4}$ Extracts of the stem bark also have antimicrobial and cytotoxic activity. ${ }^{14}$ The species showed anti-inflammatory, ${ }^{15}$ antitumor ${ }^{16}$ and agglutinating and immobilizing activities. ${ }^{17}$ The plants also have strong antimicrobial agents. ${ }^{18,10}$ Different parts of the $P$. serratum plant including leaves, roots, fruits, and seeds have potential antioxidant, ${ }^{11}$ anti-inflammatory, ${ }^{15}$ larvicidal and other medicinal properties. ${ }^{19}$

The plants also possess anti-tumor activities ${ }^{16}$ and immobilizing activities. ${ }^{17}$ It also has been evaluated the anti-arthritic activities of the plant. ${ }^{12}$ The plant extracts has an effect on the breast cancer cells. ${ }^{20}$ The wood of $P$. serratum is well textured, hard and excellent for making furniture ${ }^{21}$,house posts and boards. ${ }^{7,3}$ The wood also used for purposes of millwork, veneer and plywood, general construction, particleboards and such others. ${ }^{22}$ The tree generally harvested by local or ethnic people from the forests for its value as a fruit, preparation of folk medicine and source of wood. This ecologically important and valuable multipurpose tree is becoming rare in Bangladesh day by 
day. Naturally P. serratum is propagated by seeds and regeneration in natural forests is poor. The aim of the present study was to find out the germination behavior and initial seedling growth performance of $P$. serratum in nursery stage for massive plantation to protect this valuable species from extinct and to restoration of degraded land as a part of ecological restoration.

\section{Methodology}

\section{Seed collection, handling, processing and study site preparation}

Seeds of $P$. serratum were collected from Kaptai, Chittagong Hill Tracts South Forest Division, Bangladesh during September 2012. Phenotypic characteristics of fruits and seeds were then measured in the Seed Research Laboratory of Institute of Forestry and Environmental Sciences, Chittagong University (IFESCU). Fruits which randomly selected for experiment were average ranges from sizes of 1.6-1.8 cm $\times 1.4-1.7 \mathrm{~cm}$. About 250-400 fruits and 2800-2900 seeds were measured per kg respectively. After measurement, seeds were extracted manually from fruits and drying in the open sun for sowing in polybags and propagator house. Damaged, decayed and insect attacked seeds were avoided at the time of sowing. The media of the polybags was prepared with topsoil collected from forest floor, and cow-dung in the ratio of 3:1, and the media used in propagator house $^{1}$ was with fine Sylhet sand. ${ }^{2}$

\section{Experimental design}

Nine treatments with three replications for each and 20 seeds in each replication were set in the experiment. For justification of seed germination behavior and seedling growth performances of the treated seeds in eight plots with pre-sowing treatments and a sample plot was designed with non-treated seeds called control. Total experimental design was randomized completely block design. The pre-treatment methods were as follows:

$\mathrm{T}_{0}$ : Seeds with no treatment and sown in polybags only (Control)

$\mathrm{T}_{1}$ : Seeds treated with sand paper at the distal end

$\mathrm{T}_{2}$ : Seeds soaking in water at $24^{\circ} \mathrm{C}$ for 24 hours

$\mathrm{T}_{3}$ : Seeds soaking in hot water for 1 minute

$\mathrm{T}_{4}$ : Seeds immersed in $10 \% \mathrm{H}_{2} \mathrm{SO}_{4}$ for 1 minute

$\mathrm{T}_{5}$ : Seeds immersed in $10 \% \mathrm{H}_{2} \mathrm{SO}_{4}$ for 3 minutes

$\mathrm{T}_{6}$ : Seeds immersed in $10 \% \mathrm{HCl}$ for 1 minute

$\mathrm{T}_{7}$ : Seeds immersed in $10 \% \mathrm{HCl}$ for 3 minutes

$\mathrm{T}_{8}$ : Seeds sown in propagator house

In sand paper treatment $\left(\mathrm{T}_{1}\right)$ seeds were manually rubbed with sand paper at the distal end. Seeds were put into a beaker and soaked for 24 hours at room temperature $\left(24^{\circ} \mathrm{C}\right)$ in cold water treatment $\left(\mathrm{T}_{2}\right)$. In hot water treatment $\left(\mathrm{T}_{3}\right)$ seeds were put into a beaker and soaked in boiled water (immediately after reaching boiling point) for 1 minute. In acid treatments $\left(\mathrm{T}_{4}, \mathrm{~T}_{5}, \mathrm{~T}_{6}\right.$ and $\left.\mathrm{T}_{7}\right)$, randomly selected seeds were put into four separate beakers and immersed in $10 \%$ concentrated $\mathrm{H}_{2} \mathrm{SO}_{4}$ and $\mathrm{HCl}$ separately and left for 1 and 3 minutes respectively

${ }^{1}$ Propagator house: is a structure, primarily of glass, in which temperature and humidity can be controlled for the cultivation or protection of plants. Propagator house is one type of greenhouse with a bed consists of Sylhet sand with controlled temperature and humidity.

${ }^{2}$ Sylhet sand: River sand with higher proportion of silica found in Sylhet region, Bangladesh. for both acids. After immersion, the solution was drained off and repeatedly rinsed with running tap water. Seeds in control and presowing treatments from $T_{1}-T_{7}$ were sown in polybags, whereas $T_{8}$ was conducted in propagator house at comparatively higher temperature $\left(35^{\circ} \mathrm{C}\right.$ temperature), humidity and in controlled environment.

\section{Data collection and analyze}

Germination behaviors were recorded in daily basis at the date of seed sowing and continued up to six months. Germination percentage measured by counting seeds germinated daily out of $100 \cdot{ }^{23}$ Cumulative germination percent measured at the end of total seed germination by summed up daily germination. The germination energy assessed by calculating daily germination percentage of its peak time. ${ }^{24}$ Survival percentages was determined by counting total seedlings survived at the end of the experiment. Germination value was found after multiplying peak value of germination (PV) and mean daily germination (MDG).

The following formulas were used to find out germination percentage, cumulative germination percentage, rate of germination, plant percent and plant value:

$$
\begin{aligned}
& \text { Germination } \%=\frac{\text { Numberofseedsgerminated }}{\text { Numberofseedssown }} \times 100 \\
& \text { Cumulative germination } \%=\frac{\text { Cumulativenumberofseedsgerminated }}{\text { Numberofseedssown }} \times 100 v \\
& \text { Germination rate } \%=\frac{\text { Numberofseedsgerminated }}{\text { Numberofday }} \times 100
\end{aligned}
$$$$
\text { Plant } \%=\frac{\text { Numberofsurvivingseedlings }}{\text { Numberofseedssown }} \times 100
$$

Ger $\min$ ation value $=$

Peakvalueofger $\min$ ation $(P V) \times$ Meandailyger $\min$ ation $(M D G)$

Germination capacity is the percentage of seeds in a sample that actually germinate irrespective of time. The germination capacity was categorized by Kumar $1999^{23}$ as - i) $100-90 \%$ - very good, ii) $90-70 \%-$ good, iii) $70-50 \%$-average, iv) $50-30 \%$-poor, v) $30-20 \%$-very poor, and vi) $(<) 10 \%$ - extremely poor.

The experiment was conducted in the natural atmospheric condition. Regular weeding and watering twice daily were maintained. Only in treatment $T_{8}$, temperature and humidity was controlled relatively high and stayed apart from rainfall. Daily sprinkling at two times was provided for required water and moisture. Seedlings growth behavior was measured at two different stages -five months and seven months for finding out growth increment rate among different treatments. Shoot height, leaf number, leaf length and width were measured when seedlings were five months old. Collar diameter was measured at seventh month when seedlings were ready for plantation. For counting leaf number total number of nodes including both leaf fall scar and leaf present was counted and average number was calculated. Shoot height, leaf length and leaf width were measured with centimeter scale while collar diameter was measured with vernier caliper.

\section{Results and discussion}

\section{Germination behaviors}

Germination behaviors of $P$. serratum were differently affected by applying different pre-sowing treatments. Germination started at first $\left(13^{\text {th }}\right.$ day) in seeds treated with $10 \% \mathrm{HCl}$ acid solution for 1 minute and maximum days (90 days) was taken by those seeds treated with 
boiled water for 1 minute. At the end of study highest cumulative germination $(30 \%)$, plant percent $(30 \%)$ and germination value $(0.4)$ were observed in seeds sown without any treatments. Germination energy was highest $(6.7 \%)$ both in boiled water and $\mathrm{HCl}$ for 3 minutes treatments. Based on germination percentage, seed sown without any treatment showed comparatively better germination capacity while seeds sown after different treatments showed very poor and extremely poor germination capacity (Table 1 ).

Table I Variation in germination behavior of $P$. serratum under different pre-sowing treatments

\begin{tabular}{|c|c|c|c|c|c|c|c|c|}
\hline Treatments & $\begin{array}{l}\text { Germi- } \\
\text { nation start } \\
\text { at (day) }\end{array}$ & $\begin{array}{l}\text { Germi- } \\
\text { nation } \\
\text { ended after }\end{array}$ & $\begin{array}{l}\text { Cumu-lative } \\
\text { germi- } \\
\text { nation \% }\end{array}$ & $\begin{array}{l}\text { Germi- } \\
\text { nation } \\
\text { energy \% }\end{array}$ & $\begin{array}{l}\text { Germination } \\
\text { energy period } \\
\text { (week) }\end{array}$ & $\begin{array}{l}\text { Plant } \\
\text { percent } \\
\%\end{array}$ & $\begin{array}{l}\text { Germi- } \\
\text { nation } \\
\text { value }\end{array}$ & $\begin{array}{l}\text { Germi-nation } \\
\text { capacity }\end{array}$ \\
\hline $\mathrm{T}_{0}($ Control $)$ & $22^{\text {th }}$ & $178^{\text {th }}$ & $30 c^{*}$ & $5 a$ & $8 a$ & $30 c$ & $0.4 b$ & Poor \\
\hline $\mathrm{T}_{1}$ (Sand paper) & $17^{\text {th }}$ & $155^{\text {th }}$ & $15 b$ & $5 a$ & $4 a$ & $15 b$ & $0.2 \mathrm{a}$ & Very poor \\
\hline $\mathrm{T}_{2}$ (Cold water, 24 hr.) & $21^{\text {th }}$ & $148^{\text {th }}$ & II.7ab & $5 a$ & $9 \mathrm{a}$ & II.7ab & $0.1 \mathrm{a}$ & Very poor \\
\hline $\mathrm{T}_{3}$ (Boiled water, I min.) & $90^{\text {th }}$ & $170^{\text {th }}$ & $5 a$ & $6.7 b$ & $13 b$ & $5 a$ & 0.0 & Extremely poor \\
\hline $\mathrm{T}_{4}\left(\mathrm{H}_{2} \mathrm{SO}_{4}, \mathrm{I} \mathrm{min}.\right)$ & $21^{\text {th }}$ & $160^{\text {th }}$ & $23.3 b c$ & $5 a$ & $5 a$ & $23.3 b c$ & $0.12 \mathrm{a}$ & Very poor \\
\hline $\mathrm{T}_{5}\left(\mathrm{H}_{2} \mathrm{SO}_{4}, 3 \mathrm{~min}.\right)$ & $17^{\text {th }}$ & $155^{\text {th }}$ & $28.3 c$ & $5 a$ & $4 a$ & $28.3 c$ & $0.27 a b$ & Very poor \\
\hline $\mathrm{T}_{6}(\mathrm{HCl}, \mathrm{I} \mathrm{min})$. & $13^{\text {th }}$ & $126^{\text {th }}$ & $10 \mathrm{a}$ & $5 a$ & $\mathrm{IIb}$ & $10 \mathrm{a}$ & $0.07 a$ & Extremely poor \\
\hline $\mathrm{T}_{7}(\mathrm{HCl}, 3 \mathrm{~min})$. & $15^{\text {th }}$ & $170^{\text {th }}$ & $25 \mathrm{bc}$ & $6.7 b$ & $6 a$ & $25 b c$ & $0.29 \mathrm{ab}$ & Very poor \\
\hline $\mathrm{T}_{8}$ (Propagator House) & - & - & - & - & - & - & - & - \\
\hline
\end{tabular}

* Means followed by the same letter ( $\mathrm{s}$ ) are not significantly different at $\mathrm{P}<0.05$, Duncan's Multiple Range Test (DMRT).

\section{Mean cumulative germination percentage}

Mean cumulative germination percentage (MCG\%) varied differently with different treatments and time. MCG\% was found highest at early stage ( $16^{\text {th }}$ day) in $\mathrm{HCl}(3 \mathrm{~min})$ treatment. After one month it was highest in $\mathrm{H}_{2} \mathrm{SO}_{4}(3 \mathrm{~min})$ treatment and remain constantly highest up to $93^{\text {rd }}$ day followed by $\mathrm{HCl}$ treatment for 3 minutes. At the end of six months all curves showed significant distinction from their previous results that found at the end of three months. Maximum treatments showed a continuous progressive nature from $3^{\text {rd }}$ to $6^{\text {th }}$ month while a few showed rapid germination at this stage. Seeds sown in control revealed highest MCG\% and most steep curve since $3^{\text {rd }}$ to $6^{\text {th }}$ month of seed sowing (Figure 1 ).

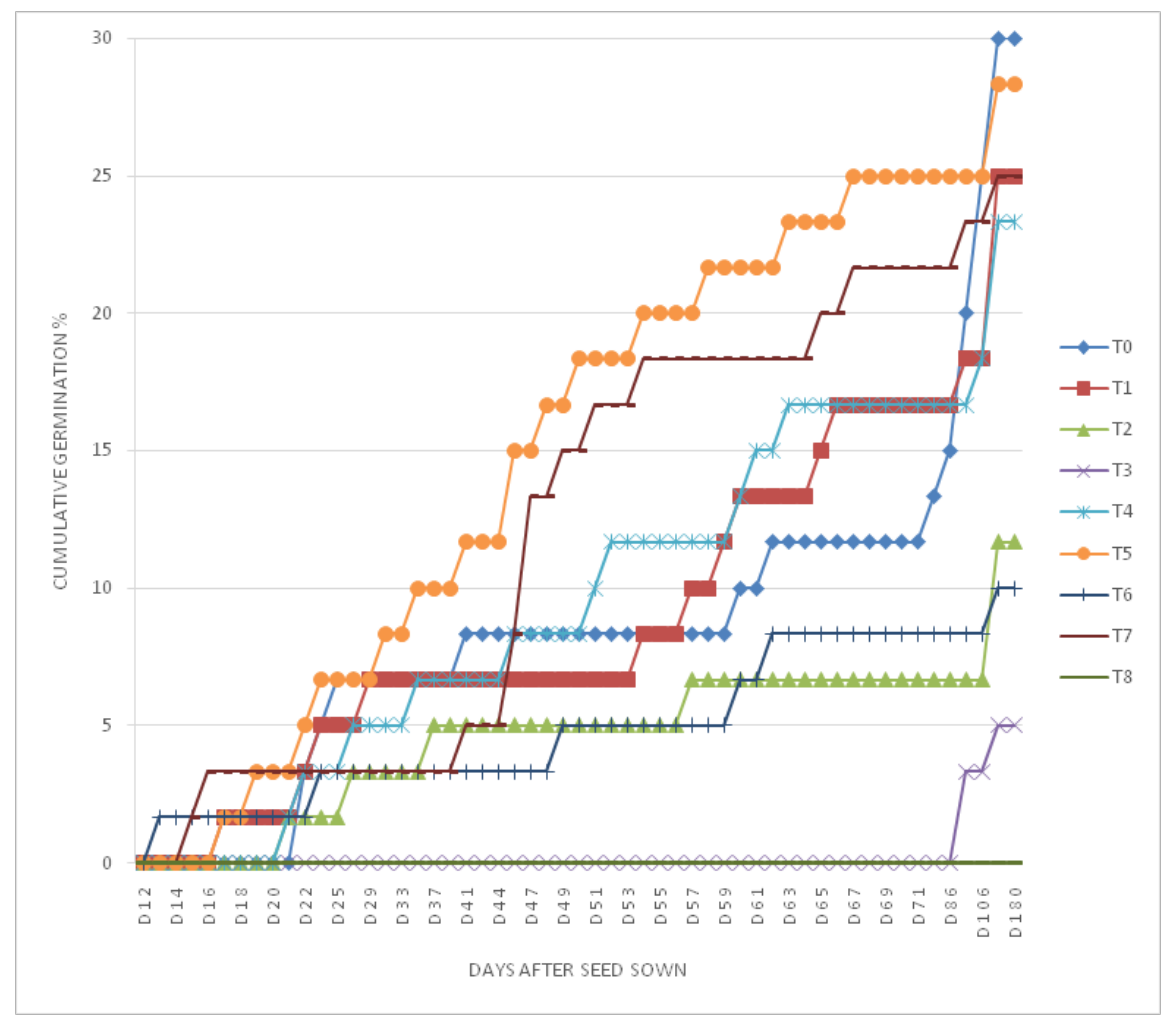

Figure I Mean cumulative germination percent of $P$. serratum under different treatments. 


\section{Seedling morphology}

Highest shoot height $(28.8 \mathrm{~cm})$ observed in seedlings germinated after treating with $10 \%$ concentrated $\mathrm{HCl}$ acid for 3 minutes followed by $10 \% \mathrm{H}_{2} \mathrm{SO}_{4}$ for 3 minutes $(28.2 \mathrm{~cm})$ and $10 \% \mathrm{H}_{2} \mathrm{SO}_{4}$ for 1 minute
(26 cm). Surprisingly, unlike other acid treatments $10 \% \mathrm{HCl}$ for 1 minute revealed comparatively low $(13.5 \mathrm{~cm})$ height increment. Leaf number (16), leaf size $(12.7 \mathrm{~cm} \times 4.7 \mathrm{~cm})$ and collar diameter (12) were also maximum in seedlings germinated by $10 \%$ concentrated $\mathrm{HCl}$ acid treatment for 3 minutes (Table 2).

Table 2 Mean morphological growth of $P$. serratum seedlings in different treatments

\begin{tabular}{|c|c|c|c|c|c|}
\hline \multirow{3}{*}{ Treatments } & \multicolumn{5}{|c|}{ Seedlings after germination } \\
\hline & \multicolumn{4}{|l|}{ Five months old } & \multirow{2}{*}{$\begin{array}{l}\text { Seven months old } \\
\text { Collar diameter }(\mathrm{mm})\end{array}$} \\
\hline & Shoot height $(\mathrm{cm})$ & Leaf number & Leaf length (cm) & Leaf width (cm) & \\
\hline $\mathrm{T}_{0}$ (Control) & 14.8 & 12 & 10.4 & 3.8 & 9 \\
\hline $\mathrm{T}_{1}$ (Sand paper) & 18.8 & 13 & 10.9 & 3.9 & 10 \\
\hline $\mathrm{T}_{2}$ (Cold water, $24 \mathrm{hr}$.) & 11.3 & 8 & 10.8 & 4.5 & 8 \\
\hline $\mathrm{T}_{3}$ (Boiled water, I min.) & 2.6 & 3 & 5.8 & 2.6 & 5 \\
\hline $\mathrm{T}_{4}\left(\mathrm{H}_{2} \mathrm{SO}_{4}, \mathrm{I}\right.$ min. $)$ & 26 & 15 & 11.9 & 4.5 & 9.2 \\
\hline $\mathrm{T}_{5}\left(\mathrm{H}_{2} \mathrm{SO}_{4}, 3 \mathrm{~min}.\right)$ & 28.2 & 16 & 12.1 & 4.5 & 9.4 \\
\hline $\mathrm{T}_{6}(\mathrm{HCl}, \mathrm{I} \mathrm{min})$. & 13.5 & 9 & 10.9 & 4.3 & 7.8 \\
\hline $\mathrm{T}_{7}(\mathrm{HCl}, 3 \mathrm{~min})$. & 28.8 & 16 & 12.7 & 4.7 & 12 \\
\hline
\end{tabular}

\section{Discussion}

Hard coated seeds are sometimes impermeable to required nutrition for producing vigor seedlings. These seeds need proper presowing treatments for producing potential seedlings for plantation and for restoration of land. Germination behaviors and seedling morphological behaviors of $P$. serratum were positively varied with different pre-sowing treatments. Soaking in proper concentrated acid sometimes enhances germination rate. Seeds soaked sufficiently in acid may boost germination rate in some hard-coated seeds. ${ }^{25-28}$ But, insufficient soaking may not effective enough. Moreover, concentration of acid and time of exposure are very critical and varies from species to species. In this study only one concentration $(10 \%$ solution) and two time of exposures ( 1 and 3 minutes) to $\mathrm{HCl}$ and $\mathrm{H}_{2} \mathrm{SO}_{4}$ was used. Soaking seeds in $\mathrm{HCl}$ soften the hard coat of seeds and make the seed coat permeable to water, air and nutrition. ${ }^{26,29}$ After the pretreatment when seeds sown immediately sucked water and nutrient for producing vigor seedlings easily from the soil. Hot water treatment reveled poor performances both in germination and seedling growth. This may be because of damage of embryo due to extreme heat. Further researches could be conducted with hot water treatments of different heats.

Though cumulative germination behaviors were highest in seeds sown without any pre-sowing treatment followed by seeds treating with $10 \%$ concentrated $\mathrm{H}_{2} \mathrm{SO}_{4}$ for 3 minutes and $10 \%$ concentrated $\mathrm{HCl}$ for 3 minutes, but overall seedling growth performances were highest in seedlings obtained from seeds sown after treating with $10 \%$ $\mathrm{HCl}$ followed by $10 \% \mathrm{H}_{2} \mathrm{SO}_{4}$ for 3 minutes and $10 \% \mathrm{H}_{2} \mathrm{SO}_{4}$ for 1 minute. The study revealed that, seeds sown after application of acid treatments were more effective than any other pretreatment methods. In this result, it was also found that with increase of soaking time in both acids seed germination behaviors and seedling morphological growth behaviors increased positively. These findings will be helpful for conducting further researches.

\section{Conclusion}

The wild fruit tree species $P$. serratum has ecological value and allelopathic importance. Fruits of this species are quite familiar and eaten by people living in Chittagong Hill Tracts (CHT). But, this tree is becoming rare in its natural habitat gradually. Natural regeneration and survivability is in risk and restoration of land with this important native tree species is only possible by plantation. Commercial plantation with other fruit trees could save the species from becoming extinct. In natural habitat though the germination rate is quite similar to nursery but survivability due to predation and climatic hazard it is difficult to grow in a mature vigor tree. Hence, seedlings grow in nursery could be the only alternative for restoration. For raising vigor seedlings for plantation $10 \%$ concentrated $\mathrm{HCl}$ acid for 3 minutes and $10 \% \mathrm{H}_{2} \mathrm{SO}_{4}$ for 3 minutes both are recommended. Further researches are recommended by applying different concentration of $\mathrm{HCl}$ and $\mathrm{H}_{2} \mathrm{SO}_{4}$ for different immersion periods.

\section{Acknowledgments}

None.

\section{Conflicts of interest}

Authors declare that there is no conflicts of interest.

\section{References}

1. Swart JJ. A monograph of the genus Protium and some allied genera (Burseraceae) (Doctoral dissertation, Drukkerij koch en knuttel); 1942.

2. Roskov Y, Kunze T, Orrell T, et al. Species 2000 \& ITIS catalogue of life: 2014 annual checklist". Species 2000: Reading, UK; 2014

3. Gardner S, Sidisunthorn P, Anusarnsunthorn V. A field guide to forest trees of northern Thailand. Kobfai Publishing Project; 2000.

4. Huq AM, Hasan H. Flora of Bangladesh (Burseraceae). Dhaka: Bangladesh Agricultural Research Council; 1987.

5. Islam MR, Kabir MF, Alam R, et al. Sedative, membrane stability, cytotoxic and antioxidant properties of methanol extract of leaves of Protium serratum Wall. Asian Pacific Journal of Tropical Disease. 2014;4:928-933.

6. Hassler M. World Plants: Synonymic checklists of the vascular plants of the world (version Dec 2017). In: Roskov Y \& Abucay L. editors. Species 2000 \& ITIS Catalogue of Life; 2018. 
7. Woodcock HD, Coutts J. Lilies: Their culture and management. Country Life Limited, London; 1935.

8. Fujii Y, Parvez SS, Parvez MM, et al. Screening of 239 medicinal plant species for allelopathic activity using the sandwich method. Weed Biol Manag. 2003;3(4):233-241.

9. Prakash D, Upadhyay G, Gupta C. Total phenol and antioxidant activity of some fruits and their under-utilized parts. International Food Research Journal. 2013;20(4):1717.

10. Panda SK, Mohanta YK, Padhi L, Park YH, Mohanta TK, Bae H. Large scale screening of ethnomedicinal plants for identification of potential antibacterial compounds. Molecules. 2016;21:1-20.

11. Mohanta YK, Panda SK, Bastia AK, Mohanta TK. Biosynthesis of silver nanoparticles from Protium serratum and investigation of their potential impacts on food safety and control. Frontiers in microbiology. 2017;8:626.

12. Sayeed MA, Rashid MMU, Kabir MF, Alam R, Islam MS, Dhar R, Yusuf AM. In vitro anti-arthritic and thrombolytic activities of methanolic extract of Protium serratum leaves. Journal of Medicinal Plants Research. 2014;8(16):615-618.

13. Kandi B, Dhal NK, Mohanty RC. A case study on indigenous phytotherapy for skin diseases in Nuapada district, Odisha, India. Int $J$ Herb Med. 2013;1(2):117-123.

14. Ara K, Rahman MS, Rahman AHMM, Hasan CM, Rashid MA Terpenoids and Coumarin from Bursera serrata Wall. Dhaka Univ JPharm Sci2009;8(2):107-110.

15. Carretero ME, López - Pérez JL, Abad MJ, Bermejo P, Tillet S, Israel A, Noguera PB. Preliminary study of the anti-inflammatory activity of hexan e extract and fractions from Bursera simaruba (Linneo) Sarg. (Burseraceae) leaves. J Ethnopharmacol. 2008;116:1115 .

16. McDoniel PB, Cole JR. Antitumor activity of Bursera schlechtendalii (burseraceae): isolation and structure determination of two new lignans. J Pharm Sci. 1972;61:1992-1994.

17. Huacuja RL, Delgado NM, Carranco LA, Reyes LR, Rosado GA Agglutinating and immobilizing activity of an e thanol extract of Bursera fagaroides on human and other mammalian spermatozoa. Arch Invest Med. 1990;21:393-398.
18. Panda SK. Ethno-medicinal uses and screening of plants for antibacterial activity from similipal biosphere reserve. Odisha, India. $J$ Ethnopharmacol. 2014;151:158-175.

19. Tanamatayarat P. Antityrosinase, antioxidative activities, and brine shrimp lethality of ethanolic extracts from Protium searratum (Wall. ex Colebr.) Engl. Asian Pac J Trop Biomed. 2016;6:1050-1055.

20. Chan LL, Gosangari SL, Watkin KL, Cunningham BT. A label-free photonic crystal biosensor imaging method for detection of cancer cell cytotoxicity and proliferation. Apoptosis. 2007;12(6):1061-1068.

21. Sutton BC, Mehrotra MD. Colletogloeum protii sp. nov., a leaf spot pathogen of Protium serratum. Transactions of the British Mycological Society. 1982;78(1):188-190.

22. Chudnoff M. Tropical Timbers of the World. USDA Forest Service, Ag. Handbook no. 607. USDA, Washington, DC, USA; 1984.

23. Kumar V. Nursery and Plantation Practices in Forestry. Scientific Publishers, 5A, New Pali Road, P.O. Box 91, Jodhpur - 342001; 1999.

24. Dwivedi AP. A Text Book of Silviculture. International Book Distributors 9/3 Rajpur Road, Dehradun - 248001, India; 1993.

25. Msanga HP. Seed Germination of Indigenous Trees in Tanzania, UBC Press, Vancouver, Canada; 2000.

26. Azad MS, Biswas RK, Matin MA. Seed germination of Albizia procera (Roxb.) Benth in Bangladesh: a basis for seed source variation and presowing treatment effect. Forestry Studies in China. 2012;14(2):1241130 .

27. Merou T, Takos I, Konstantinidou E, et al. Effect of different Pretreatment methods on germination of Albizia julibrissin seeds. Seed Science and Technology. 2011;39(1):248-252.

28. Azad MS, Zedan-Al-Musa M, Matin MA. Effects of pre-sowing treatments on seed germination of Melia azedarach. Journal of Forestry Research. 2010;21(2):193-196.

29. Schmidt L. Dormancy and Pre-Treatment. Guide to Handling of Tropical and sub-Tropical Forest Seeds, Danida Forest Seed Centre, Humlebaek, Denmark; 2000. 